SHS Web of Conferences 23, 04004 (2016)

DOI: $10.1051 /$ shsconf/ 20162304004

C) Owned by the authors, published by EDP Sciences, 2016

\title{
A Review of Literature on At-Risk Adolescent Students in Malaysia: Needing an Academic Resilience Model
}

\author{
Shahabuddin Hashim, Seffetullah Kuldas, and Hairul Nizam Ismail, \\ School of Educational Studies, Universiti Sains Malaysia, Malaysia
}

Email: Shah@usm.my

\begin{abstract}
This review article synthesises evidence for a growing concern over delinquency and crimes, such as alcohol, drug, and sexual abuse, among adolescent students in Malaysia. Some of the students can be academically successful despite risk factors that prevent the majority of others with the same background from succeeding. This exceptional academic achievement raises the question of what and how resilience assets enable some students to perform the same task better than others who have the same background. How Malaysian adolescent students develop academic resilience against risk factors is unclear. The review argues that this issue should be brought to light, so that an academic resilience model is developed for non-resilient students. Such a model would allow teachers to establish a caregiving relationship with their non-resilient students, help them counteract risk factors, and, thus, make a positive difference in their lives.
\end{abstract}

Keywords: Adolescent Student, Risk Factor, Academic Resilience, Resilience Asset

\section{Introduction}

Adolescence can be a period of dramatic changes and challenges, as the period of physical and personal development from youth into adulthood (Arnett 1999). Although this stressful period is not universal (Eccles et al. 1993), many adolescents suffer from conflictual relationships with their parents, teachers, peers, or friends in Malaysia (Hashim 2007).

This review sets out reasons for developing an academic resilience model to help Malaysian adolescent students who face adversities. Rendering students academically resilient and intellectually rigorous is a universal objective of educational endeavours, as in Malaysia. The Ministry of Education Malaysia has enjoined public educational institutions to render their students as resilient learners, effective problem solvers, critical and creative thinkers, so that they can overcome adversities (Curriculum Development Centre 1989). Students may hereby gain admittance to advanced education and living opportunities (Benard 1995). To achieve the objective, adversities students face and reduce their potential to achieve should be taken into account (Hanewald 2011). According to literature reviewed, students' poor performance in academic or cognitive tasks can be associated with their experience of adversity, but some of them can still be academically resilient. Academic resilience is hereby defined solely by exceptional academic achievement in the face of adversity (Morales 2008). How adolescent 
students in Malaysia construct, develop, and demonstrate academic resilience has yet to be examined. As Miller (2002) and Russo and Boman (2007) argued, this issue should be brought to light, so that an optimal academic resilience model is developed for non-resilient students in Malaysia.

This review article consists of three main sections. The first explains resilience, its internal and external assets, and risk factors. The second presents risk factors that Malaysian adolescent students have experienced. The third highlights the need for the academic resilience approach. The review suggests further studies to explain how to help students who are not academically resilient.

\section{Resilience and Risk Factors: Internal and External Assets}

Is resilience a developmental process or personality trait? Zimmerman and Arunkumar (1994) stated that resilience is not an individual trait or a fixed quality that a person has or has not. "Resilience does not come from rare and special qualities, but from the everyday magic of ordinary, normative human resources in the minds, brains, and bodies of children, in their families and relationships, and in their communities" (Masten 2001, p. 9). Thus, resilience encompasses human cognitive, affective, social, and physical development (Lee et al. 2010). However, not all people are able to demonstrate their potential resilience; a reason can be the underdevelopment of internal and external resilience assets (protective factors).

The "internal resilience assets" usually refer to cognitive factors, which are problem-solving skills, social competence, critical consciousness of the self, a sense of purpose, and autonomy (Benard 1995). The problem-solving skills encompass critical, creative, and reflective thinking. The social competence refers to communication skills, the ability to understand feelings and problems of others and to elicit their positive responses. The critical consciousness is one's reflective awareness of the source of adversity and one's creativity in developing coping strategies. The sense of purpose contains hopefulness, achievement motivation, and educational aspirations. Finally, the sense of autonomy is the ability to exert some control over one's environment and to make sense of one's own identity.

A growing body of literature (e.g. Abdul Kadir et al. 2012; Benard 2004; Doll et al. 2011; Flouri et al. 2010; Masten et al. 1990; Rutter 1987; Werner \& Smith 1992) shows that caregiving relationships of an adolescent with significant individuals in family, school, and community environments are potential "external resilience assets" - protective factors that decreases the probability of negative outcomes. Examples of external protective factors are: (a) individual: better academic achievement, improvement of social skills, and secure attachment to family; (b) family: employment and caring parents; (c) school: recognition of the achievement and better opportunities for success; and (d) community: participation in a social group and access to social support. The literature suggests that the caregiving relationship promotes internal resilience assets and academic success while protecting against risk factors. 
A risk factor is usually deemed to be a variable that increases the probability of negative outcome (Durlak 1998). Examples of risk factors are: (a) individual: sexual abuse, sexrelevant risk behaviour, and substance abuse; (b) family: neglect, unemployment, and low socioeconomic status; (c) school: poor attachment to school, peer pressure, and academic failure; and (d) community: a lack of concern and social support. Students who have experienced a risk factor in the past or present may demonstrate poor performance in academic tasks (Doll et al. 2011; Flouri et al. 2010; Hanewald 2011). A number of longitudinal studies (e.g. Cicchetti \& Manly 2001; Lansford et al. 2002) reported that children who suffer neglect are at risk of depression, anxiety, delinquency, and academic failure during childhood, adolescence, and adulthood.

\section{Are Malaysian Adolescent Students At-Risk?}

The population of Malaysian adolescent (10-19 years old) was estimated to be 5.5 million (UNICEF 2010), while of Malaysian youth (15-25 years old) was about 5.2 million in 2010 (Department of Statistics Malaysia 2010). This is approximately $19 \%$ of the total population. Relying on the World Youth Report (2005), Abdul Kadir and colleagues (2012) estimated that $25 \%$ of the youth population would be classified as at-risk youth.

Hashim (2007) claimed that "Malaysian teenagers, in general, face various life challenges and experience distress. They are at risk of becoming dissatisfied and unhappy teenagers and may choose to become involved in negative activities such as gangsterism, bullying, drug abuse, sexual misconduct, and crime" (p. 112). A series of recent studies drew attention to that commitment of crimes, such as pornography, destructive behaviour, truancy (Mey 2010), and drug addicts (Ghani et al. 2008) among Malaysian youths have been increased, thereby increasing concern over juvenile delinquency (Nasir et al. 2010). Outstandingly, most drug addicts, who were 31-40 years old, reported that they started using drugs when they were in secondary school in the country (Ghani et al. 2008). The risk behaviours have significant associations with neglect in the form of an unestablished caregiving relationship with parents and other individuals in school and neighbourhood environments. In a relevant study (Low et al. 1996), Malaysian teenagers perceived negative parental attitudes as factors leading to drug abuse; the teenagers associated their unfulfilled needs with not being respected, loved, or treated fairly by their parents. In a further research (Low et al. 2007), Malaysian adolescent boys, aged between 13 and 17 years, ascribed their involvement in premarital sex to tension and pressure from family. However, in another study (Zulkifli \& Low 2000), adolescents who were living away from their parents had more experience of premarital sex, which could be due to peer group pressure and influences of social interactions. As such, risk factors in all these cases are attributable to the absence of a caregiving relationship with parents, friends, or peer groups.

Talib and colleagues (2012) asserted that there is a considerable number of sexually active teenagers and teenage pregnancy in Malaysia. According to Talib and colleagues, $43 \%$ of youth respondents had started to have dates as early as their ages of 13-15. At the age of 16$17,35 \%$ of them had begun to caress and kiss their partners. In particular, teenage pregnancy 
has emerged to be a significant social issue, as its prevalence is increasing in the country (Tan et al. 2012). The prevalence among 4,500 teenagers (12-19 years old) had increased to 5.4\% in Negeri Sembilan (Lee et al. 2006). A similar study, by Anwar et al. (2010), reported a much higher prevalence; $12.6 \%$ among 1,139 students (15-20 years old) in Pulau Pinang. These risk factors are mostly attributable to neglect (e.g. family is not a source of strength or not close enough), unemployment, and lower levels of educational and socioeconomic status (Tan et al. 2012).

In a study on a total of 1,049 incarcerated adolescents (aged 12-19 years) in Malaysia (Nik Farid et al. 2013), a history of sexual abuse during childhood was the strongest predictor of premarital sex. Among these adolescents, 654 with the mean age of 14 reported premarital sexual intercourse. Nik Farid and colleagues stressed that child abuse associates with higher rates of depression. In a study by Abdul Kadir and Desa (2013), Malaysian female university students who suffered from depression reported an experience of physical and sexual abuse as well as parental antipathy and neglect during childhood. According to Kassim and Kasim (1995), child sexual abuse is significantly associated with family related risk factors, such as neglect, unemployment, and lower levels of educational and socioeconomic status.

Alongside neglect, physical (e.g. slapping face or head), emotional (e.g. insulting or embarrassing) (Kasim et al. 1994), and sexual violence against children is a worldwide problem, as in Malaysia. A total of $6.8 \%$ of 616 respondents, Malaysian nurse students and medical assistant trainees, informed about sexual abuse during their childhood (Singh et al. 1996). A meta-analysis of prevalence rates of sexual abuse during childhood across countries indicated that $8.3 \%$ of Malaysian women respondents had suffered some form of sexual abuse prior to their age of 18 (Pereda et al. 2009). This prevalence rate would be higher in the current time, inasmuch as the meta-analysis has relied on one early study by Singh et al. (1996). In a study (Choo et al. 2011), one in every three Malaysian participants, 15-17 years old adolescents, reported multiple experiences across the types of violence. The violence had the strongest association with the lack of good relationship with parents as well as individuals in school and neighbourhood environments.

Family, community, and individual related risk factors can give rise to academic underachievement and dropping out of school in many countries, as in Malaysia (Tan et al. 2012). To protect Malaysian children and adolescents against risk factors, Nik Farid and colleagues (2013) suggested developing innovative programmes, such as workshops on parenting skills, to help caregivers grasp the importance of nurturing their children. For a similar suggestion, Weatherley and colleagues (2012) highlighted the paucity of studies on the sexual abuse of children in Malaysia and drew attention to the need for a school-based sexual abuse prevention curriculum. For better innovative programmes or effective curriculum, encouraging or discouraging factors underlying child abuse and other risk behaviour relevant sexual intercourse need to be investigated. The risk and protective factors relevant to academic resilience could be considered. 
According to Hashim (2007), "the increasing social problems among teenagers in Malaysia are, in fact, a manifestation of their inability to cope with the challenges of everyday life" ( $p$. 98). The inability to deal with stress alongside with socioeconomic disadvantaged backgrounds and peer pressure appeared to be the major reasons for substance abuse (Baharudin et al. 2011). Similar reasons are also attributable to premarital sex and teenage pregnancy (Tan et al. 2012). According to the Malaysian Youth Report (Hamzah 2007), substance use and premarital sexual intercourse are the most prevalent risk behaviour among the adolescents. As such, future studies should be aimed at identifying at risk youth, developing the resilience model, thus, designing programmes that can facilitate and foster the development of internal and external resilience assets.

\section{Calling for the Academic Resilience Approach}

Abdul Kadir and colleges (2012) argued that Malaysian adolescent students who are at-risk require a caregiving relationship with an adult who assists them with love, care, and attention. A caregiving relationship with parents, peers, friends, or teachers means that the student atrisk has always someone who cares who he or she is, listening and talking to him or her. Students who are provided with a caregiving relationship may demonstrate satisfactory academic achievements (academic resilience) despite their disadvantaged backgrounds (Martin \& Marsh 2006). Non-resilient students can hereby develop resilience to avoid risk behaviour.

Such suggestions for the caregiving relationship is congruent with the "Educational Resilience Theory" (Wang et al. 1994). Stemming from Ecological Systems Theory (Bronfenbrenner 1979), Educational resilience theory (Wang et al. 1999) proposes that caregiving relationships between individuals in family, school, or social community need to be established, so that students can demonstrate academic resilience. According to this proposition, students may confront adversities anytime or everywhere whereby they need to draw on their resilience assets. The resilience assets empower individuals to mould an environment they are in, which in turn form their developmental processes. This is a widely accepted ecological framework for understanding the internal and external resilience assets, the dynamic interactions between risk and protective factors (see Doll et al. 2011; Esquivel et al. 2011; Gordon \& Song 1994; Von Soest et al. 2010).

Although individuals essentially use their internal resilience assets, they show resilience with the help of the external resilience assets (Rutter 1987). The family factor is the most caregiving environment to develop the internal resilience while schools and peers significantly increase the resilience level (Brooks 2006). Teachers can promote the internal resilience by having a caregiving relationship (Werner \& Smith 1992). A teacher can provide an adolescent student with opportunities that are based on reciprocity and collaboration, such as giving a role to participate in teaching and learning activities instead of control and competition. Such an opportunity increases intrinsic motivation and enhances the ability to learn in the classroom (Benard 2004). Withholding the student from such opportunities usually leads to detachment from the teachers (WestEd 2002). The cumulative impact of the external resilience assets 
increases positive outcomes, such as avoiding academic failure and coping with adjustment problems (Werner 1993; Werner \& Smith 1992).

As a result, the academic resilience approach is based upon the basic tenet that everyone has potential resilience that enables not only to rebound from adversity, but also to succeed in spite of it. The resilience approach suggests focusing on protective factors promoting the potential resilience, thereby academic success, rather than on eliminating the risk factors that promote failure (Grotberg 1995). Promoting all the resilience assets is not necessary, but solely improving one of them is not enough to make a student sufficiently resilient (Grotberg 1995). An adolescent may be loved but is less likely to show effective resilience against challenges if he or he lacks the necessary self-awareness. A person may have high selfawareness but is not resilient enough if he or she has nobody to help him or her. Effective resilience results from a combination of the assets. How individual, family, societal, and school assets aggregately conduce to academic resilience needs to be examined further, so that programmes can be designed to strengthen resilient behaviours (Willms 2002). A further study may draw on the academic resilience approach to explain how Malaysian adolescent students develop their academic resilience.

\section{Conclusion}

This review has synthesised evidence for the need of an academic resilience model to support at-risk Malaysian adolescent students. Despite the obstacles that prevent the majority of students with the same background from succeeding, some students can be academically successful (demonstrate academic resilience). Empirical data concerning how Malaysian adolescent students construct their academic resilience has yet to be provided. Further studies could be aimed at (a) identifying their academic resilience assets (b) predicting the best external assets that promote internal assets, and (c) determining the best internal assets associated with high academic achievement.

\section{References}

Abdul Kadir, N. B., \& Desa, A. (2013). Preliminary data on abuse during childhood among female university students. Asia Pacific Journal of Social Work and Development, 23, 299-314. 10.1080/02185385.2013.826903

Abdul Kadir, N. B., Rahim, S. A., Mustapha, Z., Abdul Mutalib, M. H., Kee, C. P., \& Mohamed, R. H. (2012). External assets as predictors of positive emotions among at-risk youth in Malaysia. Asian Social Work and Policy Review, 6, 203-217.

Anwar, M., Sulaiman, S. A. S., Ahmadi, K., \& Khan, T. M. (2010). Awareness of school students on sexually transmitted infections (STIs) and their sexual behavior: A crosssectional study conducted in Pulau Pinang, Malaysia. BMC Public Health, 10(1), 47.

Arnett, J. J. (1999). Adolescent storm and stress, reconsidered. American Psychologist, 54, 317-326. doi:10.1037/0003-066X.54.5.317 
Baharudin, R., Krauss, S. E., Yaacob, S. N., \& Pei, T. J. (2011). Family processes as predictors of antisocial behaviors among adolescents from urban, single-mother Malay families in Malaysia. Journal of Comparative Family Studies, 42, 509-522.

Benard, B. (1995). Fostering resilience in children. ERIC Clearinghouse on Elementary and Early Childhood Education, University of Illinois.

Benard, B. (2004). Resiliency: What have we learned? San Francisco: WestEd.

Bronfenbrenner, U. (1979). The ecology of human development: Experiments by nature and design. Cambridge, MA: Harvard University Press.

Brooks, J. (2006). Strengthening resilience in children and youths: Maximizing opportunities through the schools. Children and Schools, 28, 69-76.

Cicchetti, D., \& Manly, J. (2001). Operationalizing child maltreatment: Developmental processes and outcomes. Development and Psychopathology, 13, 755-757.

Curriculum Development Centre (1989). Integrated curriculum for secondary schools. Kuala Lumpur, Malaysia: Minister of Education (p. 1.2.6.27).

Choo, W. Y., Dunne, M. P., Marret, M. J., Fleming, M., \& Wong, Y. L. (2011). Victimization experiences of adolescents in Malaysia. Journal of Adolescent Health, 49, 627-634. doi:10.1016/j.jadohealth.2011.04.020

Department of Statistics Malaysia (2010). Statistics handbook Malaysia, 2010. Kuala Lumpur: Department of Statistics.

Doll, B., Jones, K., Osborn, A., Dooley, K., \& Turner, A. (2011). The promise and the caution of resilience models for schools. Psychology in the Schools, 48, 652-659.

Durlak, J. A. (1998). Common risk and protective factors in successful prevention programs. American Journal of Orthopsychiatry, 68, 512-520. doi:10.1037/h0080360

Eccles, J. S., Midgley, C., Wigfield, A., Buchanan, C. M., Reuman, D., Flanagan, C., \& Mac Iver, D. (1993). Development during adolescence: The impact of stage-environment fit on young adolescents' experiences in schools and in families. American Psychologist, 48, 90-101. doi:10.1037/0003-066X.48.2.90

Esquivel, G. B, Doll, B., \& Oades-Sese, G. V. (2011). Introduction to the special issue: Resilience in schools. Psychology in the Schools, 48, 649-651. doi:10.1002/pits.20585

Flouri, E., Tzavidis, N., \& Kallis, C. (2010). Adverse life events, area socioeconomic disadvantage, and psychopathology and resilience in young children: The importance of risk factors accumulation and protective factors' specificity. European Child \& Adolescent Psychiatry, 19, 535-546. doi:10.1007/s00787-009-0068-x

Ghani, S. A., Zamani, Z. A., Rahman, R. M. A., Zainal, A. H., \& Sulaiman, W. S. W. (2008). Family functioning and its relation with self-esteem among drug addicts. Jurnal Antidadah Malaysia, 3, 91-106.

Gordon, E. W., \& Song, L. D. (1994). Variations in the experience of resilience. In M. C. Wang, \& E. W. Gordon (Eds.), Educational resilience in inner-city America: Challenges and prospects (pp. 27-43). Hillsdale, NJ: Lawrence Erlbaum.

Grotberg, E. H. (1995). A guide to promoting resilience in children: Strengthening the human spirit. The Hague, The Netherlands: Bernard van leer foundation.

Hamzah, A. (2007). Situation of girls and young women in Malaysia. Malaysian Youth Report, 2007. Kuala Lumpur: Ministry of Youth and Sport. 
Hanewald, R. (2011). Reviewing the literature on "at-risk" and resilient children and young people. Australian Journal of Teacher Education, 36, 16-29.

Hashim, I. H. M. (2007). Stress, coping and social supports in the adolescent years. Kajian Malaysia, 25(1), 97-115.

Kasim, M. S., Shafie, H. M., \& Cheah, I. (1994). Social factors in relation to physical abuse in Kuala Lumpur, Malaysia. Child Abuse \& Neglect, 18, 401-407.

Kassim, K., \& Kasim, M. S. (1995). Child sexual abuse: Psychosocial aspects of 101 cases seen in an urban Malaysian setting. Child Abuse \& Neglect, 19, 793-799.

Lansford, J., Dodge, K., Pettit, G., Bates, J., Crozier, J., \& Kaplow, J. (2002). A 12-year prospective study of the long-term effects of early child physical maltreatment on psychological, behavioral, and academic problems in adolescence. Archives of Pediatrics \& Adolescent Medicine, 156, 824-83

Lee, L. K., Chen, P. C., Lee, K. K., \& Kaur, J. (2006). Premarital sexual intercourse among adolescents in Malaysia: A cross-sectional Malaysian school survey. Singapore Medical Journal, 47, 476-481.

Lee, T., Kwong, W., Cheung, C., Ungar, M., \& Cheung, M. Y. L. (2010). Children's resilience-related beliefs as predictor of positive child development in the face of adversities: Implications for interventions to enhance children's quality of life. Social Indicator Research, 95, 437-453. doi:10.1007/s11205-009-9530-x

Low, W. Y., Ng, C. J., Fadzil, K. S., \& Ang, E. S. (2007). Sexual issues: Let's hear it from the Malaysian boys. The Journal of Men's Health \& Gender, 4, 283-291.

Low, W. Y., Zulkifli, S. N., Yusof, K., Batumalail, S., \& Aye, K. W. (1996). The drug abuse problem in Peninsular Malaysia: Parent and child differences in knowledge, attitudes and perceptions. Drug and Alcohol Dependence, 42, 105-115.

Martin, A. J., \& Marsh, H. W. (2006). Academic resilience and its psychological and educational correlates: A construct validity approach. Psychology in the Schools, 43, 267-281. doi:10.1002/pits

Masten, A. S. (2001). Ordinary magic: Resilience processes in development. American Psychologist, 56, 227-238.

Masten, A. S., Best, K. M., \& Garmezy, N. (1990). Resilience and development: Contributions from the study of children who overcome adversity. Development and Psychopathology, 2, 425-444.

Mey, S. C. (2010). Psychological profile of adolescents in Malaysia. The International Journal of Educational and Psychological Assessment, 4, 77-96.

Miller, M. (2002). Resilience elements in students with learning disabilities. Journal of Clinical Psychology, 58, 291-298. doi:10.1002/jclp.10018

Morales, E. E. (2008). The resilient mind: The psychology of academic resilience. The Educational Forum, 72, 152-167. doi:10.1080/00131720701805017

Nasir, R., Zamani, Z. A., Yusooff, F., \& Khairudin, R. (2010). Cognitive distortion and depression among juvenile delinquents in Malaysia. Procedia-Social and Behavioral Sciences, 5, 272-276. doi:10.1016/j.sbspro.2010.07.087

Nik Farid, N. D., Che'Rus, S., Dahlui, M., \& Al-Sadat, N. (2013). Determinants of sexual intercourse initiation among incarcerated adolescents: a mixed-method study. Singapore Medical Journal, 54, 695-701. doi:10.11622/smedj.2013244 
Pereda, N., Guilera, G., Forns, M., \& Gómez-Benito, J. (2009). The prevalence of child sexual abuse in community and student samples: A meta-analysis. Clinical Psychology Review, 29, 328-338. doi:10.1016/j.cpr.2009.02.007

Russo, R., \& Boman, P. (2007). Primary school teachers' ability to recognise resilience in their students. The Australian Educational Researcher, 34, 17-33.

Rutter, M. (1987). Psychosocial resilience and protective mechanisms. American Journal of Orthopsychiatry, 57, 316-31. doi:10.1111/j.1939-0025.1987.tb03541.x

Singh, H. S., Yiing, W. W., \& Nurani, H. N. K. (1996). Prevalence of childhood sexual abuse among Malaysian paramedical students. Child Abuse and Neglect, 20, 487-492.

Talib, J., Mamat, M., Ibrahim, M., \& Mohamad, Z. (2012). Analysis on sex education in schools across Malaysia. Procedia-Social and Behavioral Sciences, 59, 340-348.

Tan, P. S., Tohid, H., Su, X. V., Tan, K. T. M., Azimah, M. N., \& Khairani, O. (2012). A study of pregnant adolescents residing in a government home: Common characteristics and their views on the pregnancy. Malaysian Family Physician, 7(1), $11-15$.

UNICEF (2010). Malaysia Statistics. $\quad$ Retrieved from http://www.unicef.org/infobycountry/malaysia_statistics.html\#96.

Von Soest, T., Mossige, S., Stefansen, K., \& Hjemdal, O. (2010). A validation study of the resilience scale for adolescents (READ). Journal of Psychopathology and Behavioral Assessment, 32, 215-225. doi:10.1007/s10862-009-9149-x

Wang, M. C., Haertel, G. D., \& Walberg, H. J. (1994). Educational resilience in inner cities. In M. C. Wang \& E. W. Gordon (Eds.), Educational resilience in inner-city America: Challenges and prospects (pp. 45-72). Hillsdale, NJ: Lawrence Erlbaum.

Wang, M.C., Haertel, G. D., \& Walberg, H. J. (1999). Psychological and educational resilience. In A. J. Reynolds, H. J. Walberg, \& R. P. Weissberg (Eds.), Promoting positive outcomes: Issues in children's and families' lives (pp.329-366). Washington, DC: CWLA Press.

Weatherley, R., Siti Hajar, A. B., Noralina, O., John, M., Preusser, N., \& Yong, M. (2012). Evaluation of a school-based sexual abuse prevention curriculum in Malaysia. Children and Youth Services Review, 34(1), 119-125. doi:10.1016/j.childyouth.2011.09.009

Werner, E. E. (1993). Risk, resilience, and recovery. Perspectives from the Kauai longitudinal study. Development and Psychopathology 5, 503-515.

Werner, E. E., \& Smith, R. S. (1992). Overcoming the odds: High-risk children from birth to adulthood. Ithaca, New York: Cornell University Press.

WestEd. (2002). Resilience and youth development module: Aggregated California data fall 1999 to spring 2002. Los Alamitos, CA: Author.

Willms, J. D. (2002). Vulnerable Children. Findings from Canada's national longitudinal survey of children and youth. The University of Alberta Press, Alberta, Canada

Zimmerman, M. A., \& Arunkumar, R. (1994). Resiliency research: Implications for schools and policy. Social Policy Report, 8, 1-17.

Zulkifli, S. N., \& Low, W. Y. (2000). Sexual practices in Malaysia: Determinants of sexual intercourse among unmarried youths. Journal of Adolescent Health, 27, 276-280. 